\title{
Risk Assessment of Groundwater Quality: A Case Study in Flood-Prone Neighbourhood Area of Pondidaha, Southeast Sulawesi
}

\author{
Nurmaladewi ${ }^{1}$ Yetty Septiani Mustar ${ }^{2 *}$ \\ ${ }^{1}$ Department of Public Health, Universitas Haluoleo, Kendari, Indonesia \\ ${ }^{2}$ Department of Health Education and Recreation, Universitas Negeri Surabaya, Surabaya, Indonesia \\ *Corresponding author. Email: yettymustar@unesa.ac.id
}

\begin{abstract}
Groundwater quality is crucial for human life. Water resources and quality are also closely related to human health, as they can be utilized as a domestic resource. Water quality can be disrupted due to various contaminants and sediments caused by floods, which negatively impact human health, mortality, environmental losses, cultural heritage, and economic activities associated with flood events. Pondidaha is one of the sub-districts in Konawe Regency, Southeast Sulawesi, which is prone to flooding. The problem faced in flood-prone areas is water quality. This study aims to analyze the risk assessment of water quality in a flood-prone area. A total of 10 groundwater sampling stations were selected based on flood-affected villages, consisting of five main parameters: $\mathrm{pH}, \mathrm{BOD}, \mathrm{COD}, \mathrm{DO}$, and NH3N. The results of our study indicate that the groundwater sample is below the threshold value of the quality standard, so it is feasible as a source of raw material for drinking water. Assessing the vulnerability and health risks of water contaminants is essential to raise awareness about the potential hazards and risks they pose. Hence, risk assessment of groundwater quality regularly should be carried out to identify the potential dangers and other sources of pollutants affecting groundwater to prevent the risk of harm to human health.
\end{abstract}

Keywords: Water quality, Flood-prone, Potential hazard, Health risk.

\section{INTRODUCTION}

Floods are among the most common natural disasters in various countries, which potentially threaten human life, cause environmental damage and economic losses [1]. Floods are caused by both biological factors and human activities. Natural elements are highly dependent on the rainfall conditions, groundwater system (geohydrology), geological structure, rock types, geomorphology, land topography, and climate change, resulting in a dynamic and significant increase in rainfall. At the same time, human activities are related to behavior in natural exploitation that is carried out with high intensity and less controlled [2], [3]. Globally, the frequency of floods has a massive impact on the lives of both developing and developed countries [4]. The catastrophic floods worldwide were responsible for nearly 53,000 deaths in the last decade (23:1 in lowversus high-income countries) [5].

On the other hand, flooding also seriously impacts public health, accumulation of domestic waste, the number of pathogenic bacteria and disease vectors around inundated waters, which causes potential outbreaks of infectious diseases, increases in vector and water-borne conditions [6]-[8]. Research conducted by Naing et al. [9] showed that flooding is significantly associated with increasing cases of leptospirosis. Dengue fever cases experienced a massive spike in Pakistan due to increased mosquito vector breeding sites during floods [10]. Furthermore, research conducted in Western Uganda bordering a flooded river showed that extreme flooding increased malaria incidence by approximately $30 \%$ compared to villages far from the river [11]. Additionally, other researchers also proved that flooding could also endanger human health through infection in wounds [12], diarrhea [13]-[15], and post-traumatic stress disorder among refugees [16].

In recent years, Indonesia experienced increasing water-related disasters, which resulted in many lives and severely impacted the economy. It is estimated that more than 110 million people in around 60 cities are highly vulnerable to natural hazards, including tsunamis, earthquakes, floods, and the impacts of climate change [17]. The most frequent disasters were floods out of the total hydrometeorological disasters in Indonesia [18]. Estimated flood damage in Indonesia in 2010 was US\$ 
0.8 billion, US\$ 3 billion in 2013[19]. Sulawesi is one of the islands in Indonesia, and it is well-known that most of the territory is highly vulnerable to disaster due to its geographical and geological conditions [20].

Konawe Regency is particularly the flood-prone areas inundated or flooded Southeast Sulawesi Province due to rising sea levels [21]. In addition, the annual rainfall pattern in Konawe Regency ranges from 1,500-1,900 $\mathrm{mm}$, which is also the cause of flooding in several areas in the Konawe Regency [22]. The Konawe flood in 2019 inundated 144 villages and 22 sub-districts in 24 subdistricts. Around 5,847 families or 2,573 people became flood victims due to high rainfall [23]. Eight hundred seven displaced residents suffer from various diseases that interfere with health, and six other people have been referred to the hospital [24]. Besides, infrastructure damage also occurred in the housing, education, social, agriculture, fisheries, and other public facilities sectors. Six hundred eighty-eight houses were submerged, 192 heavily damaged, 513 moderately damaged, and 575 lightly injured. In addition, the flood damaged 32 kindergartens, 49 elementary schools, and 14 junior high schools. Another loss was in the rice field sector, and floods inundated 3,246 ha of paddy fields, 357 ha of corn, and 385 ha of others [25].

However, the most severe impact of floods is the contamination of water such as surface water, groundwater (can be either deep well water or shallow well water), and distribution systems on a large scale [26]. Groundwater is the primary water source, and its quality is essential because it is extensively used as a source of drinking water for the population. Increasing various pollutant particles during flooding [27] could affect surface groundwater's chemical quality with the dilution of physical and chemical parameters of water, low mineral, and organic components in water [28]. Thus, contaminated drinking water with microorganisms, chemical compounds, and other pollutants can cause various risk factors of severe diseases [29], [30]. Hence, it is imperative to conduct a water quality risk assessment to improve our understanding of the potential hazards of polluted water and determine effective prevention programs for further deterioration of groundwater quality and minimize health risks.

\section{METHODS}

\subsection{Study Design and Sampling Sites}

This is an experimental research design. This research design is used to explore the analysis of water quality risk assessment in flood-prone areas. This study focused on the Pondidaha Subdistrict, Konawe Regency, Southeast Sulawesi, the flood-affected area with the highest number of victims. Determination of the location of groundwater sources is carried out using the purposive sampling technique, based on the closest distance from the primary water source in Pondidaha District; the well is not flooded and is an open well. Thus, based on these criteria, a total of 10 wells became the center of our research.

\subsection{Sample Collection and Analytical Method}

Sampling for water quality inspection is conducted by physical observation of the water and then sent to the laboratory for further analysis. The risk assessment parameters of water quality in this study are the degree of acidity $(\mathrm{pH})$, biochemical oxygen demand or biological oxygen demand (BOD), chemical oxygen demand (COD), dissolved oxygen (DO), and total ammonia concentration (NH3-N). The water sampling technique is carried out based on Standard Operating Procedures (SOP) for water quality sampling conducted by Wang et al. [31] through collecting well water samples at a depth of 0.5 meters from the healthy water surface. During loading the water into HDPE bottles, the formation of air bubbles is avoided and preserved using aluminum foil. The purpose of wrapping this aluminum foil is to delay biological activity and reduce physical and chemical changes in water [32]. Furthermore, the water samples were stored in an icebox at a temperature of $4^{\circ} \mathrm{C}$. The method used for water quality in the laboratory is presented in table 1 .

Table 1. Water quality analytical method

\begin{tabular}{|c|l|c|c|}
\hline No & Parameter & Unit & Method \\
\hline 1 & $\mathrm{pH}$ & $\mathrm{mg} / \mathrm{L}$ & $\begin{array}{c}\text { APHA, 2005, 4500- } \\
\mathrm{H}+-\mathrm{B}\end{array}$ \\
\hline 2 & $\mathrm{BOD}$ & $\mathrm{mg} / \mathrm{L}$ & $\mathrm{SNI} 6989.72: 2009$ \\
\hline 3 & $\mathrm{COD}$ & $\mathrm{mg} / \mathrm{L}$ & $\mathrm{SNI} 6989.73: 2009$ \\
\hline 4 & $\mathrm{DO}$ & $\mathrm{mg} / \mathrm{L}$ & $\mathrm{SNI} 6989.57: 2009$ \\
\hline 5 & $\mathrm{NH} 3-\mathrm{N}$ & $\mathrm{mg} / \mathrm{L}$ & $\mathrm{SNI}$ 06-6876-2002 \\
\hline
\end{tabular}

\subsection{Statistical Analysis}

We utilized the STATA application (Version 14) to perform data analysis. The data were analyzed descriptively by presenting the distribution of frequency, mean (Standard Deviation (SD)), and graphs based on the water quality assessment analysis result.

\section{RESULTS AND DISCUSSION}

Groundwater plays a significant role in supporting human life and activities [33] and is the primary source of drinking water in the study area. Therefore, water quality assessment is indispensable for identifying the pollutant that significantly poses health risks [34]. The present study determined the chemical contaminant (i.e., $\mathrm{pH}, \mathrm{BOD}, \mathrm{COD}, \mathrm{DO}$, and $\mathrm{NH} 3-\mathrm{N}$ ) in 10 water samples obtained by wells derived from selected sites in Pondidaha District, a flood-affected area, then compared it with the water quality standards in Indonesia.

The classification of water categories in Indonesia is divided into four classes, each class indicating the feasibility of being used for a particular use (called designation). Water class and water quality criteria are regulated in Government Regulation of the Republic of 
Indonesia Number 82 of 2001 concerning Water Quality Management and Water Pollution Control. In this study, the quality standards for water quality assessment are aimed at the class 1 water quality category, which can be utilized for drinking water quality standards [35]. The result of the water quality assessment and the average concentration value of water quality for each station are presented in table 2 and figure 1. Each of the water quality parameters is discussed in detail.

Table 2. The result of chemical parameters of healthy water by station

\begin{tabular}{|c|c|c|c|c|c|c|c|c|c|c|c|c|}
\hline Parameter & Unit & S.Q. & T1 & T2 & T3 & T4 & T5 & T6 & T7 & T8 & T9 & T10 \\
\hline $\mathrm{pH}$ & $\mathrm{mg} / \mathrm{L}$ & $6-9$ & 7.6 & 7.6 & 7 & 7.8 & 7.2 & 7.4 & 7 & 7 & 7.3 & 7.2 \\
\hline $\mathrm{BOD}$ & $\mathrm{mg} / \mathrm{L}$ & 2 & 0.68 & 0.64 & 0.62 & 0.74 & 0.64 & 0.61 & 0.71 & 0.6 & 0.65 & 0.6 \\
\hline $\mathrm{COD}$ & $\mathrm{mg} / \mathrm{L}$ & 10 & 0.54 & 0.57 & 0.5 & 0.62 & 0.7 & 0.73 & 0.64 & 0.56 & 0.67 & 0.7 \\
\hline $\mathrm{DO}$ & $\mathrm{mg} / \mathrm{L}$ & 6 & 1.4 & 1.42 & 1.4 & 1.53 & 1.6 & 1.4 & 1.6 & 1.44 & 1.54 & 1.5 \\
\hline $\mathrm{NH3}-\mathrm{N}$ & $\mathrm{mg} / \mathrm{L}$ & 0.5 & 0.025 & 0.035 & 0.04 & 0.042 & 0.05 & 0.052 & 0.07 & 0.47 & 0.042 & 0.04 \\
\hline
\end{tabular}

SQ - Standard Quality, $T$ - sampling station

\subsection{Potential of Hydrogen (pH)}

One of the determinants of drinking water quality is the $\mathrm{pH}$ level, which describes the acidity and alkalinity of groundwater. The results showed that the ten samples tested were slightly alkaline, maximum dose of 7.8 with an average concentration of $7.31 \pm 0.28$. This study complies with WHO recommendations and Indonesian government regulations regarding the maximum permissible quantity for $\mathrm{pH}$ concentration in drinking water [35], [36]. This finding was different from the research conducted by Nayan et al. [37], which showed the $\mathrm{pH}$ level of healthy water in flood-prone areas was low and slightly acidic, thus affecting the groundwater quality and causing the water to have a bitter and corrosive metallic taste. Low and high $\mathrm{pH}$ levels can increase the solubility of other toxic metals in water, which are very harmful to the human body [38]. In addition, high alkalinity also affects the body's normal $\mathrm{pH}$, which can neutralize and inhibit gastric juice secretion [39].

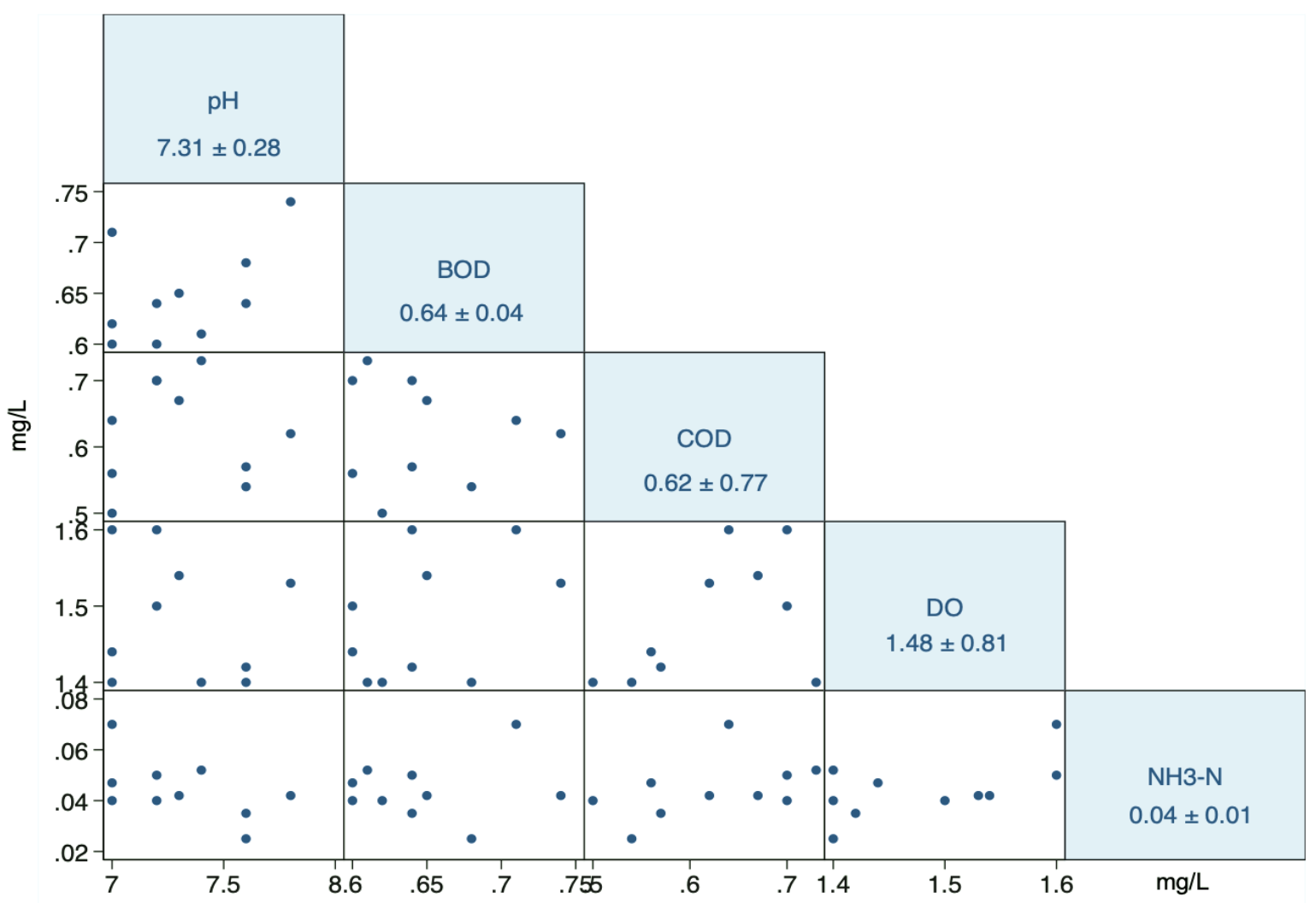

Figure 1 The average concentration value of water quality risk assessment for each station Data are presented as mean (SD)

\subsection{Biological Oxygen Demand (BOD)}

The BOD value of each station varied between $0.6-$ $0.71 \mathrm{mg} / \mathrm{L}$ with an average concentration of $0.64 \pm 0.04$ $\mathrm{mg} / \mathrm{L}$. It is shown that the water is clean and meets the recommended standards. If water with a high BOD value is consumed, it will pose a potential health threat to the community [40]. This study was consistent with other studies which showed similar low BOD concentrations $(1.0-7.0 \mathrm{mg} / \mathrm{L})$, thus indicating that the water had not been polluted [41], [42]. The BOD test is essential for 
monitoring water quality to measure dissolved oxygen required for the biochemical decomposition of organic compounds and the oxidation of some inorganic materials [43].

\subsection{Chemical Oxygen Demand (COD)}

COD is an indicator of water pollution by organic substances, oxidizing naturally through microbiological processes and reducing oxygen levels in the water [44]. The COD value at all sites does not exceed the maximum allowable dose, below ten $\mathrm{mg} / \mathrm{L}$. The average was $0.62 \pm$ $0.77 \mathrm{mg} / \mathrm{L}$, indicating that groundwater is suitable for use as raw material for drinking water. In contrast to the assessment of groundwater quality in the city of Quetta, Pakistan, this study revealed that the E.C. and COD value values of all samples exceed WHO's standards [45]. Theoretically, if COD exceeds the threshold value, the water is considered polluted and can pose a health hazard [46].

\subsection{Dissolved Oxygen (DO)}

The DO parameter can be utilized as an indicator of water freshness. The present study showed that the measured DO of all water samples ranges from 1.4-1.6 $\mathrm{mg} / \mathrm{L}$. The maximum dose of 1.6 was at stations 5 and 7 with an average concentration of $1.48 \pm 0.81$ showed this study complies with Indonesian government regulations for drinking water. On the contrary, the results of the groundwater quality assessment in Abo Shuisha showed that DO levels were higher than the WHO recommendation for drinking water [47]. The concentration of DO at the bottom of the groundwater is highly dependent on the depth of the aquifer the water comes from; Shallow groundwater aquifers have higher DO levels than those in deeper areas [48].

\subsection{Ammoniacal Nitrogen (NH3-N)}

The suitability of groundwater for drinking, irrigation, and industrial purposes depends on its quality [49]. Good quality of water will have an impact on health and ensure sustainable socio-economic development [50]. Therefore, groundwater quality needs to be adequately maintained and not polluted to protect water [51]. The maximum value of NH3-N from all sampling sites was $0.07 \mathrm{mg} / \mathrm{L}$ which is below the Indonesian leading permissible standard. This study contrasts to research conducted on groundwater in flood-prone areas of Malaysia, which shows that there are stations that record NH3-N levels that exceed the quality standard set by the Department of Environmental Health (DOE) [37].

Maintaining NH3-N at a minimum level in drinking water is crucial because ammonia compounds can cause several dangerous diseases depending on the anions that form compounds [52]. Additionally, acute exposure to NH3-N in experimental animals has implications for pulmonary edema, kidney damage, and nervous system dysfunction. Furthermore, long-term exposure to NH3-N causes a decrease in bone mass and blood $\mathrm{pH}$ [53].

\section{CONCLUSION}

The result of our study provides insight into groundwater quality, suitability, and health risk in the flood-prone neighborhood areas, Konawe Regency, Southeast Sulawesi. The maximum values for the concentration of $\mathrm{pH}, \mathrm{BOD}, \mathrm{COD}, \mathrm{DO}$, and NH3-N from all stations complies with $\mathrm{WHO}$ recommendations and the Indonesian government for drinking water. Concerning this, regularly conducting groundwater quality risk assessment is essential to identify and raise awareness of the potential hazard and other sources of pollutants affecting groundwater and determine effective programs to prevent and minimize health risks.

Our study mainly focuses on groundwater quality for several parameters of chemical compounds in floodprone areas. Future studies are expected to assess water quality using other complex parameters (i.e., other chemical compounds, physical, biological) and the precipitation during the dry and wet seasons.

\section{REFERENCES}

[1] S. E. Crawford et al., "Project house water: a novel interdisciplinary framework to assess the environmental and socio-economic consequences of flood-related impacts," Environ Sci Eur, vol. 29, no. 1, p. 23, 2017, DOI: 10.1186/s12302-0170121-1.

[2] M. Acosta-Coll, F. Ballester-Merelo, M. MartinezPeiró, and E. De la Hoz-Franco, "Real-Time Early Warning System Design for Pluvial Flash Floods-A Review," Sensors (Basel), vol. 18, no. 7, p. 2255, Jul. 2018, DOI: 10.3390/s18072255.

[3] G. Gowrisankar et al., "Chemical, microbial and antibiotic susceptibility analyses of groundwater after a major flood event in Chennai," Sci Data, vol. 4, p. 170135, Oct. 2017, DOI: 10.1038/sdata.2017.135.

[4] M. Asim et al., "Post-Traumatic Stress Disorder among the Flood Affected Population in Indian Subcontinent," Nepal J Epidemiol, vol. 9, no. 1, pp. 755-758, Mar. 2019, DOI: 10.3126/nje.v9i1.24003.

[5] K. Alderman, L. R. Turner, and S. Tong, "Floods and human health: a systematic review," Environ Int, vol. 47, pp. 37-47, Oct. 2012, DOI: 10.1016/j.envint.2012.06.003.

[6] A. N. M. Kraay, O. Man, M. C. Levy, K. Levy, E. Ionides, and J. N. S. Eisenberg, "Understanding the Impact of Rainfall on Diarrhea: Testing the Concentration-Dilution Hypothesis Using a Systematic Review and Meta-Analysis," Environ Health Perspect, vol. 128, no. 12, p. 126001, Dec. 2020, DOI: 10.1289/EHP6181.

[7] L. S. Rowles Iii et al., "Seasonal contamination of well-water in flood-prone colonies and other 
unincorporated U.S. communities," Sci Total Environ, vol. 740, p. 140111, Oct. 2020, doi: 10.1016/j.scitotenv.2020.140111.

[8] A. Y. Rosinger, "Household water insecurity after a historic flood: Diarrhea and dehydration in the Bolivian Amazon," Soc Sci Med, vol. 197, pp. 192-202, Jan. 2018, doi: 10.1016/j.socscimed.2017.12.016.

[9] C. Naing, S. A. Reid, S. N. Aye, N. H. Htet, and S. Ambu, "Risk factors for human leptospirosis following flooding: A meta-analysis of observational studies," PLoS One, vol. 14, no. 5, p. e0217643, 2019, DOI: 10.1371/journal.pone.0217643.

[10] S. B. Rasheed, R. K. Butlin, and M. Boots, "A review of dengue as an emerging disease in Pakistan," Public Health, vol. 127, no. 1, pp. 1117, Jan. 2013, DOI: 10.1016/j.puhe.2012.09.006.

[11] R. Boyce et al., "Severe Flooding and Malaria Transmission in the Western Ugandan Highlands: Implications for Disease Control in an Era of Global Climate Change," J Infect Dis, vol. 214, no. 9, pp. 1403-1410, Nov. 2016, DOI: 10.1093/indices/jiw363.

[12] J. H. Diaz, "Superficial and invasive infections following flooding disasters," Am J Disaster Med, vol. 9, no. 3, pp. 171-181, 2014, DOI: 10.5055/ajdm.2014.0169.

[13] P. N. Sari and N. Nofriya, "The Relationship of Flood Disaster With The Incidence Of Diarrhea, Water Quality And Community Resilience in Water Supply: A Case Study in The City of Bukittinggi," Jurnal Kesehatan Masyarakat Andalas, vol. 12, no. 2, Art. no. 2, Dec. 2018, DOI: 10.24893/jkma.v12i2.371.

[14] C. Jiang et al., "Climate change, extreme events and increased risk of salmonellosis in Maryland, USA: Evidence for coastal vulnerability," Environ Int, vol. 83, pp. 58-62, Oct. 2015, DOI: 10.1016/j.envint.2015.06.006.

[15] K. Levy, A. P. Woster, R. S. Goldstein, and E. J. Carlton, "Untangling the Impacts of Climate Change on Waterborne Diseases: a Systematic Review of Relationships between Diarrheal Diseases and Temperature, Rainfall, Flooding, and Drought," Environ Sci Technol, vol. 50, no. 10, pp. 4905-4922, May 2016, DOI: 10.1021/acs.est.5b06186.

[16] L. Chen and A. Liu, "The Incidence of Posttraumatic Stress Disorder After Floods: A Meta-Analysis," Disaster Med Public Health Prep, vol. 9, no. 3, pp. 329-333, Jun. 2015, DOI: 10.1017/dmp.2015.17.

[17] Asian Development Bank, INDONESIA COUNTRY WATER ASSESSMENT. Philippines: ASIAN DEVELOPMENT BANK, 2016.

[18] Kementerian Pekerjaan Umum, "Pedoman Manajemen Penanggulangan Bencana Banjir Bandang," in Pedoman Manajemen
Penanggulangan Bencana Banjir Bandang, Kementerian Pekerjaan Umum, 2012.

[19] S. Muis, B. General, B. Jongman, and P. Ward, "Future trends in flood risk in Indonesia - A probabilistic approach," Geophysical Research Abstracts, vol. 16, p. 1, 2014.

[20] L. Tondobala, "Pemahaman Tentang Kawasan Rawan Bencana dan Tinjauan Terhadap Kebijakan dan Peraturan Terkait," Jurnal Sabua, vol. 3, no. 1, pp. 58-63, 2011.

[21] L. O. S. Iman, "ANALISIS SPASIAL RISIKO BENCANA BANJIR DI KABUPATEN KONAWE UTARA," in Seminar Nasional Geomatika, Feb. 2019, vol. 3, p. 1175. doi: 10.24895/SNG.2018.3-0.1041.

[22] BPS Kabupaten Konawe, Kabupaten Konawe dalam Angka 2020. BPS Kabupaten Konawe, 2020.

[23] A. Ariansyah, "Lebih dari Lima Ribu Keluarga Terdampak Banjir Konawe," BNPB. https://bnpb.go.id/berita/lebih-dari-lima-ribukeluarga-terdampak-banjir-konawe (accessed Aug. 18, 2021).

[24] CNN Indonesia, "Ratusan Korban Banjir Konawe Terserang Penyakit," nasional. Accessed: Aug. 19, 2021. [Online]. Available: https://www.cnnindonesia.com/nasional/2019061 6201912-20-403738/ratusan-korban-banjirkonawe-terserang-penyakit

[25] CNN Indonesia, "Banjir Konawe, 49 Desa Terendam dan 8.314 Jiwa Terdampak," Jul. 19, 2020. Accessed: Aug. 19, 2021. [Online]. Available:

https://www.cnnindonesia.com/nasional/2020071 9001709-20-526282/banjir-konawe-49-desaterendam-dan-8314-jiwa-terdampak

[26] R. Sun et al., "Impacts of a flash flood on drinking water quality: a case study of areas most affected by the 2012 Beijing flood," Heliyon, vol. 2, no. 2 , p. e00071, Feb. 2016, doi: 10.1016/j.heliyon.2016.e00071.

[27] D. Ciszewski and T. M. Grygar, "A Review of Flood-Related Storage and Remobilization of Heavy Metal Pollutants in River Systems," Water Air Soil Pollut, vol. 227, no. 7, p. 239, 2016, DOI: 10.1007/s11270-016-2934-8.

[28] K. Puczko and E. Jekatierynczuk-Rudczyk, "Extreme Hydro-Meteorological Events Influence to Water Quality of Small Rivers in Urban Area: A Case Study in Northeast Poland," Sci Rep, vol. 10, p. 10255, Jun. 2020, DOI: 10.1038/s41598-02067190-4.

[29] M. F. Murshed et al., "Changes in the quality of river water before, during and after a major flood event associated with a La Niña cycle and treatment for drinking purposes," Journal of Environmental Sciences, vol. 26, no. 10, pp. 19851993, Oct. 2014, DOI: 10.1016/j.jes.2014.08.001.

[30] E. E. Yard et al., "Microbial and chemical contamination during and after flooding in the 
Ohio River-Kentucky, 2011," Journal of Environmental Science and Health, Part A, vol. 49, no. 11, pp. 1236-1243, Sep. 2014, DOI: 10.1080/10934529.2014.910036.

[31] Q. Wang, R. Munoz-Carpena, A. Foster, and K. W. Migliaccio, "Groundwater sampling: Chapter 5," 2011, Accessed: Sep. 06, 2021. [Online]. Available:

https://pubs.er.usgs.gov/publication/70056520

[32] T. Saeed, "Impact of Extreme Floods on Groundwater Quality (in Pakistan)," BJECC, vol. 4, no. 1, pp. 133-151, Jan. 2014, DOI: 10.9734/BJECC/2014/4105.

[33] S. Aouiti, F. Hamzaoui Azaza, F. El Melki, M. Hamdi, F. Celico, and M. Zammouri, "Groundwater quality assessment for different uses using various water quality indices in a semi-arid region of central Tunisia," Environ Sci Pollut Res, vol. 28 , no. 34 , pp. 46669-46691, Sep. 2021, DOI: 10.1007/s11356-020-11149-5.

[34] L. Ricolfi, M. Barbieri, P. V. Muteto, A. Nigro, G. Sappa, and S. Vitale, "Potential toxic elements in groundwater and their health risk assessment in drinking water of Limpopo National Park, Gaza Province, Southern Mozambique," Environ Geochem Health, vol. 42, no. 9, pp. 2733-2745, Sep. 2020, DOI: 10.1007/s10653-019-00507-z.

[35] Pemerintah Republik Indonesia, "Peraturan Pemerintah Republik Indonesia Nomor 82 Tahun 2001 tentang Pengelolaan Kualitas Air dan Pengendalian Pencemaran Air." Jakarta : Presiden Republik Indonesia, 2001.

[36] World Health Organization, "Guidelines for drinking-water quality, 4th edition, incorporating the 1st addendum," 2017. https://www.who.int/publications/i/item/9789241 549950 (accessed Sep. 17, 2021).

[37] N. Nayan, Y. Saleh, M. Hashim, H. Mahat, and K. L. See, "Investigating Groundwater Quality in the Flood Prone Neighborhood Area in Malaysia," $I J G$, vol. 51, no. 2, p. 123, Aug. 2019, DOI: 10.22146/ijg.35589.

[38] Z. Tang, S. Hong, W. Xiao, and J. Taylor, "Impacts of blending ground, surface, and saline waters on lead release in drinking water distribution systems," Water Research, vol. 40, no. 5, pp. 943950, Mar. 2006, DOI: 10.1016/j.watres.2005.12.028.

[39] M. Drobnik, "[Evaluation of pharmacodynamic properties of medium-mineralized alkaline water designed for distribution as bottled natural mineral water]," Rocz Panstw Zakl Hig, vol. 51, no. 4, pp. 379-384, Jan. 2000.

[40] C. Koç, “TÜRKIYE'DE BODRUM YARIMADASI İÇME SUYU KALITTESINİ ÖLÇMEDE SU KALİTE İNDEKSİ," Ömer Halisdemir Üniversitesi Mühendislik Bilimleri Dergisi, Jul. 2018, doi: 10.28948/ngumuh.444731.

[41] B. U. Ngang and V. E. Agbazue, "A Seasonal Assessment of Groundwater Pollution due to
Biochemical Oxygen Demand, Chemical Oxygen Demand and Elevated Temperatures in Enugu Northern Senatorial District, southeast Nigeria," IOSR Journal of Applied Chemistry (IOSR-JAC), vol. 9, no. 7, pp. 66-73, 2016, DOI: 10.9790/57360907016673.

[42] M. Sugirtharan and M. Rajendran, "Groundwater quality near municipal solid waste dumping site at Thirupperumthurai, Batticaloa," Journal of Agricultural Sciences - Sri Lanka, vol. 10, no. 1, Art. no. 1, Feb. 2015, DOI 10.4038/jas.v10i1.8044.

[43] Sumant Kumar and N.C. Ghosh, "Assessment of Water Quality of Lakes for Drinking and Irrigation Purposes in Raipur City, Chhattisgarh, India," International Journal of Engineering Research and Applications, vol. 5, no. 2, pp. 42-51, Jan. 2015.

[44] Kusnaedi, Mengolah Air Kotor untuk Air Minum: Memperoleh Air Bersih Dengan Teknologi Sederhana. Jakarta: Penebar Swadaya, 2010.

[45] S. S. Khan et al., "Quality Assessment of Drinking Water from the Different Colonies of Quetta City, Pakistan according to WHO Standards," Biological Forum - An International Journal, vol. 7, no. 2, pp. 699-702, 2015.

[46] W. A. Amneera, N. W. A. Z. Najib, S. R. M. Yusof, and S. Ragunathan, "Water Quality Index of Perlis River, Malaysia," vol. 13, no. 02, p. 6, 2013.

[47] World Health Organization, Guidelines for drinking-water quality: first supplement to the third edition, volume 1: recommendations. Geneva: WHO, 2006.

[48] L. Yan, M. Herrmann, B. Kampe, R. Lehmann, K. U. Totsche, and K. Küsel, "Environmental selection shapes the formation of near-surface groundwater microbiomes," Water Research, vol. 170, p. 115341, Mar. 2020, DOI: 10.1016/j.watres.2019.115341.

[49] M. Laurent, A. François, and M. J. Marie, "Assessment of groundwater quality during the dry season in Southeastern Brazzaville, Congo.," 2010, Accessed: Sep. 18, 2021. [Online]. Available: http://imsear.searo.who.int/handle/123456789/15 8166

[50] J. M. Ishaku, "Assessment of groundwater quality index for JimetaYola area, Northeastern Nigeria," Journal of Geology and Mining Research, vol. 3, no. 9, pp. 219-231, 2011.

[51] L. Yun-Zhen, H. Tao, and D. Ben-lin, "Water environmental capacity and total water pollution quantity control of Fujiang river branch Jianjiang," J. Sci. Surv. Mapp., vol. 35, no. 6, pp. 158-160, 2011.

[52] M. Atta, W. Z. W. Yaacob, O. B. Jaafar, and Z. B. Sakawi, "Ammoniacal Nitrogen Contaminated Groundwater at Taman Beringin Ex-Landfill site: Implication to Health and the Environment," p. 7, 2014. 
[53] WHO, "Ammonia in drinking water: Background document for developing WHO - Guidelines for Drinking-water Quality," Geneva, Switzerland, 2003. 